\title{
THE DECIMUS BURTON ARCH
}

It is a common circumstance for great monuments to be completed by unsympathetic hands. In opposition to the expressed intentions of Poelaert, the architect, the Palais de Justice at Brussels received a round instead of a square finish to its central tower. After two centuries the interior of Wren's masterpiece was decorated with mosaics in a strange style. In the execution of the monument to King Victor Emanuel at Rome the breadth of the original design of Sacchani was completely lost. But of all the notable monuments that have met with misfortune in their completion, perhaps none have suffered like Burton's arch at the top of Constitution Hill.

Decimus Burton was born in the year 1800, and at the age of 25 was commissioned by the Government to design this and the Hyde Park Arch. He was a comparatively young man to be entrusted with so important a work, but he entered his profession at a time when the intellect of the period was concentrated upon the revival of the pure classic ideal, when the famous Elgin marbles had but recently been acquired, when Regent Street and Regent's Park Mansions had just been completed, and when Smirke's British Museum and Wilkins' National Gallery were under contemplation. Hence under the conditions existing at the time it was much easier for a young architect of ability rapidly to acquire facility in the exposition of pure academic design than would be the case to-day.

The design of the Arch as illustrated in the frontispiece has been reproduced -from the drawing which Burton presented to the Royal Institute of British Architects, and shows it to have been conceived as a great architectural monument to be enriched with ornament and adorned with sculpture. It is clear that his intention was that it should be essentially an entrance, a great archway, and a monument in the pure classic spirit of the time. With its sculptured frieze, its delicate enrichments, its bas-reliefs, and its quadriga proportioned as a climax to the bronze figures which so beautifully finish the disengaged shafts, it attains a magnificence almost approaching the sublime. But after all, this picture was destined to remain a dream. The public, blind to its ideal beauty and seeking a means whereby to honour the Duke of Wellington, saw in the colossal proportions of the Arch a fit pedestal for an equestrian statue to be erected to his memory. Our illustration, plate 50, shows how mundane, crude, and ingenuous was the transformation which actually took place. Little wonder that Burton should have been heartbroken at the prospect of seeing his arch sacrificed to the perpetration 

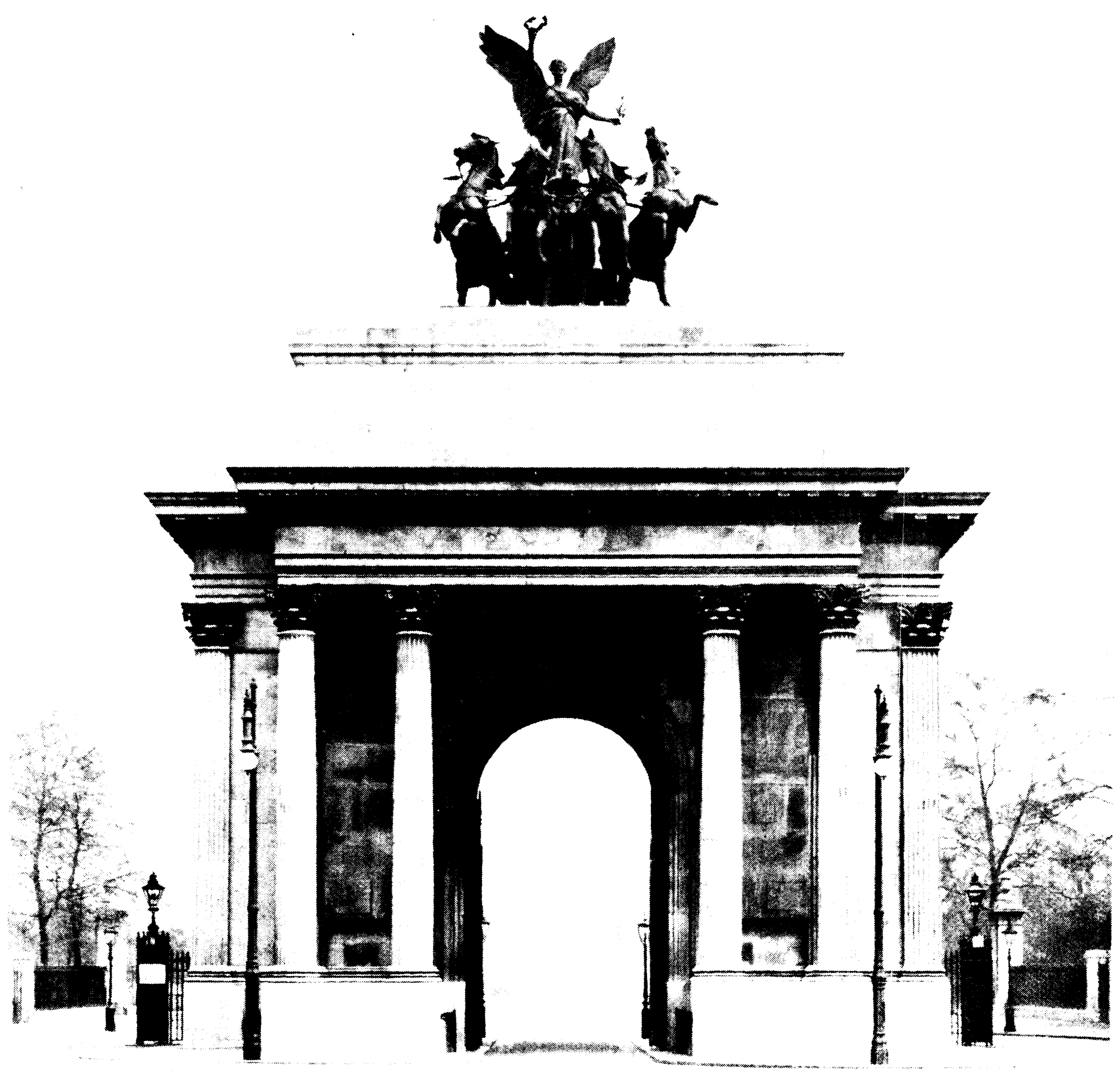

DECIMUS BURTONS ARCH AT THE TOP OF CONSTITUTION HILL. WITH THE NEW QUADRIGA BY CAPTAIN ADRIAN JONES 


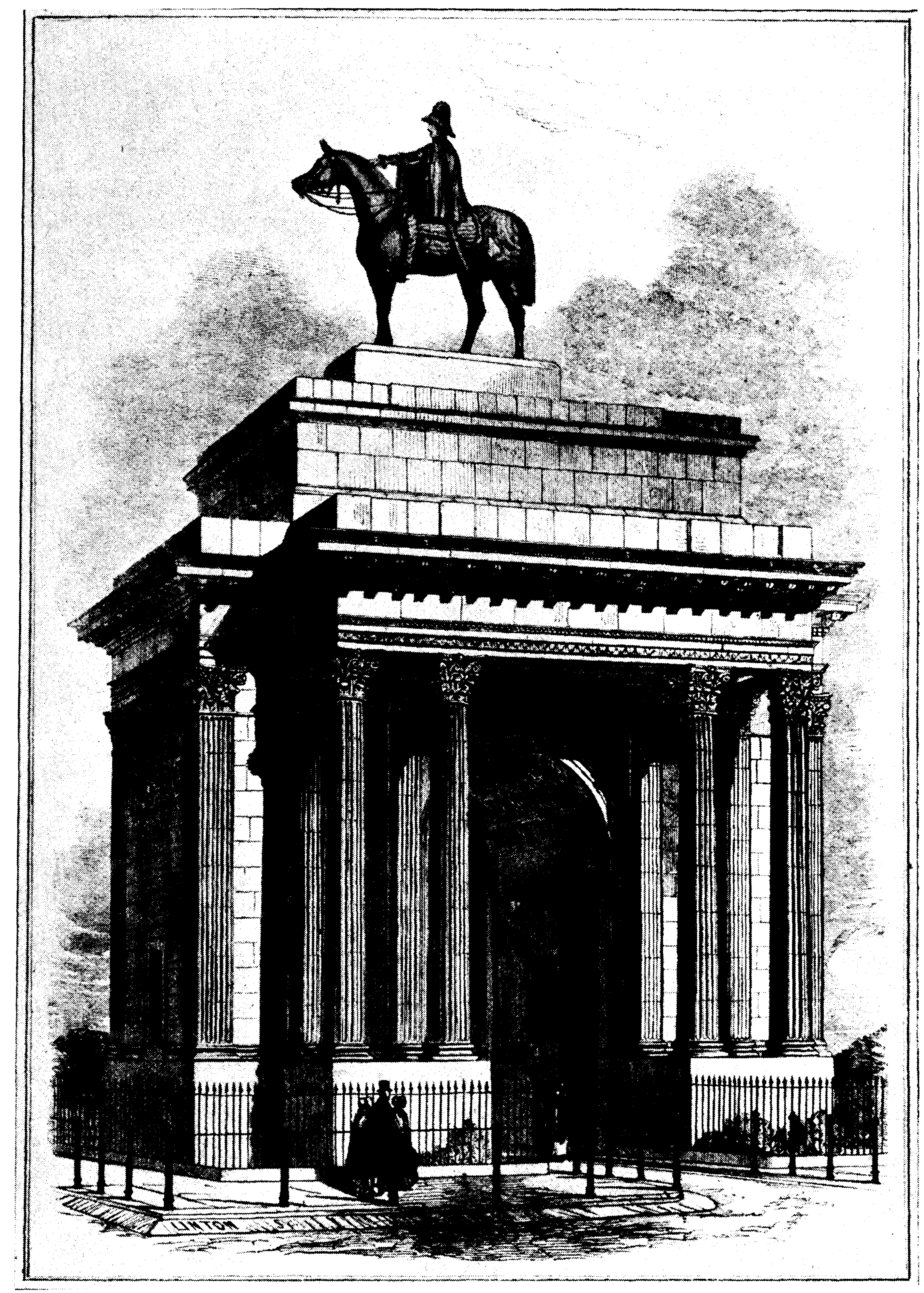

DECIMUS EURTON'S ARCH, CARRYING THE

STATUE OF THE DUKE OF WELLINGTON, REMOVED IN 1885

LONDON 
of anything so naïve. In vain did Viscount Canning write, in his official capacity from the office of Woods and Forests, to the then Duke of Rutland, the Chairman of the Committee of Subscribers to the Wellington Memorial, on the 15th of. May, 1846: "It is my duty to state to your Grace that the remonstrances which reach her Majesty's Government against the proposed appropriation of the Arch are so many and so strong, and the representations of its architect, Mr. Burton, in the same sense are so earnest; and the opinion of every other eminent architect, artist, or competent authority who has been consulted on the subject is so decided, that Her Majesty's Government feel called upon, not only to make a final effort to induce the subscribers to reconsider the subject of placing the statue on the site at present proposed, but to do all that lies in their power to facilitate a change in the design." And he proceeded to propose that the statue should be erected on a suitable pedestal of its own. But it was hopeless, it being explained that Lord Melbourne had engaged the statue to its pedestal on behalf of the subscribers seven years previously.

Of Mr. Burton's own strong feeling in the matter, he gave a remarkable practical proof in the fact that many years afterwards he made provision for the payment to the nation out of his personal estate of $£ 2,000$, if they would accede to the removal of the statue from its unsuitable position; but seeing little prospect of his hopes being fulfilled during the then present century, he before his death withdrew the legacy, cherishing, however, to his dying day the hope that the nation when it should return to, or develop, its artistic sense would remove the Wellington statue elsewhere, and carry out the quadriga and bas-reliefs to complete the work according to his original design.

Burton's death actually occurred on December 14th, 1881, and in the year 1885, Linton's famous statue of Wellington was removed to Aldershot.

As an example of the sort of jibe that was cast at this unfortunate masterpiece of crude conceit, it is said that a French officer once made the cutting ejaculation, "Nous sommes vengés," and Burton even after withdrawing his $£ 2,000$ makes the caustic remark in his will: "I give and bequeath, \&c., to the Royal Institute of British Architects the plaster casts and framed drawings of entrances at Hyde Park Corner to Hyde Park and Green Park, erected from but not completed to my designs."

But the vagaries through which this arch has had to pass have not yet ended. The arch now appeared to the public to be unfinished, as indeed it was, and a generous offer to crown it with a quadriga was accepted some years ago. All London is now acquainted with the 
famous quadriga of Captain Adrian Jones. Everyone realises that its immense scale has once more converted the arch into a pedestal and made the victorious chariot the dominating feature not only of Constitution Hill but also of Hyde Park "Place." It remains for the public to decide whether they prefer this very modern and clever piece of realism, which by the way is quite out of style with the sublime dignity of the arch, converting it into a pedestal of the most commonplace proportion, to the immense scale, the eternal proportion and the sublime dignity of Burton's dream.

S. D. Adshead. 


\section{Plate 51}

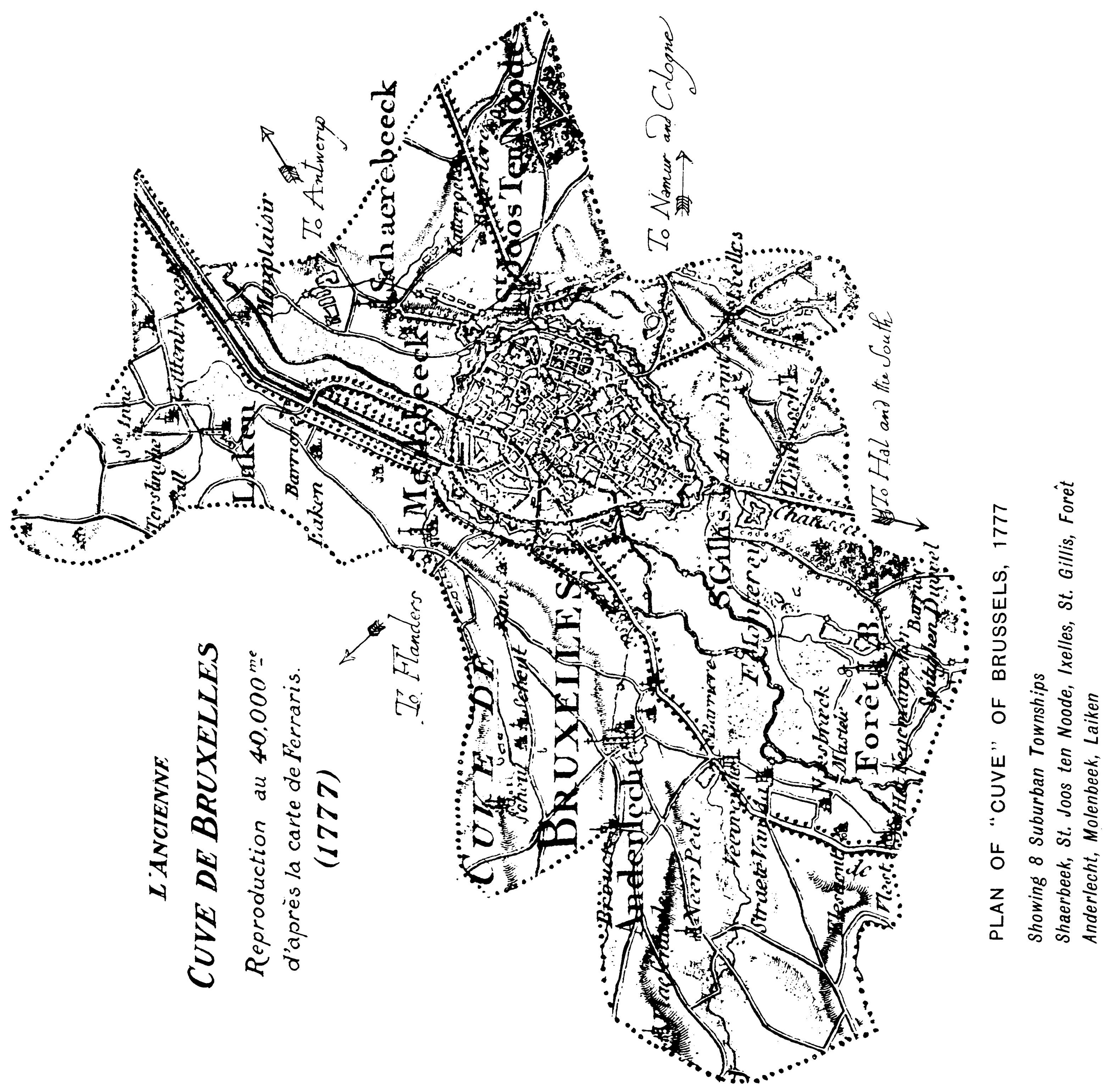

